\title{
Teaching Culture in TEFL
}

\author{
Jie Han, Liming Zhang \\ College of Foreign Language Education and International Business, Baoding University, Baoding, China \\ Email: hanjie198262@163.com
}

How to cite this paper: Han, J., \& Zhang, L. M. (2020). Teaching Culture in TEFL. Creative Education, 11, 447-451. https://doi.org/10.4236/ce.2020.114032

Received: March 14, 2020

Accepted: April 5, 2020

Published: April 8, 2020

Copyright (c) 2020 by author(s) and Scientific Research Publishing Inc. This work is licensed under the Creative Commons Attribution International License (CC BY 4.0).

http://creativecommons.org/licenses/by/4.0/

\begin{abstract}
Based upon the interdependent relationship between culture and language, this paper aims to illustrate the importance of cultural teaching in TEFL (Teaching of English as Foreign Language). At the same time, by analyzing the objectives of cultural teaching, the author also explores the means by which the teachers may conduct their cultural teaching in TEFL.
\end{abstract}

\section{Keywords}

Culture, Language, Relationship, TEFL, Positive Transition

\section{Introduction}

As an indispensable component of language, culture is often ignored by English teachers in EFL classroom. The teaching of culture, however, is of vital importance in TEFL. It is generally accepted that the objective of language teaching is to develop the students' overall language ability, namely linguistic competence, communicative competence and interactional competence. In fact, "all countries and nations should learn and draw on the strength and quintessence of others' culture". Therefore, the lack of culture teaching is becoming a serious problem which needs to be coped with. As for the cultural teaching in China, it is very important to introduce and learn foreign culture as well as maintaining and promoting the fine traditional Chinese culture. This paper is intended to find out practical approaches to carry out cultural teaching in TEFL, in the hope that it would by any chance shed some light on English teaching approaches as well as the major difficulties faced by teachers in China.

In the west, traditionally, the teaching of culture is confined to literature teaching. Stern (1983) emphasized the "cultural aspect of language teaching". Smith put forward that the goal of English teaching is to nurture and enhance the students' ability to express their views and home culture. In China, $\mathrm{Hu}$ Wenzhong introduced the term of intercultural communication from the west 
and he advocated the teaching of culture in TEFL. In general, most of the Chinese scholars focus their attention on western culture. On the contrary, Chinese culture is, to some extent, ignored. Though views on culture may vary because of different standpoints of different people, it is without any doubt that culture plays an indispensable part in English teaching.

\section{The Relationship between Culture and Language}

The relationship between culture and language is intimate and interdependent. It is universally acknowledged that culture is what is carried by language, and language is a mirror of culture. Therefore cultural teaching plays a very important role in TEFL (Teaching of English as Foreign Language).

Language is the principal means whereby we conduct our social lives (Kramsch, 2002). When it is used in context of communication, it is bound up with culture in multiple and complex ways. According to Claire Kramsch (2002), a famous American language professor at the University of California at Berkeley, language not only expresses but also embodies cultural reality. Most important of all, the former symbolizes the latter. Thus the process of learning a foreign language is also that of learning its culture. Unfortunately, to some extent, the teaching of culture has been long since ignored by Chinese teachers of English. For quite a long time our English teaching circles only emphasize the structure of English, and pay very little attention to the teaching of culture of English-speaking countries. The students are only required to remember words and expressions or recite dialogues and texts. Worst of all they regard grammar as the center of their study. Surely this makes the students get good marks in examinations, but the ignorance of cultural background results in their failure in communication in daily life.

China Daily once reported that Chinese "talking manners" disgusted a foreigner. Knowing nothing of the western concept of "privacy", some Chinese students even some college students may ask a foreigner such questions like "Where are you going?", "What's your income?", or "How much do you pay for your car?" (Qi, 1992). The writer of this article once also experienced such an event: a college invited an English teacher who was very gentle and traditional to give the students a lecture on Valentine's Day. After the lecture, the teaching asked the students to ask him questions freely. A student stood up and asked, "Do you have a girlfriend? And what did you give her on Valentine's Day?" Immediately the English gentleman flushed and answered embarrassedly "Yes, a rose." Apparently the student does not know that marriage is privacy for English people, which is definitely an integral part of their culture.

From the above examples, it is easy to draw the conclusion that one cannot exactly understand and properly use a foreign language without knowing its culture. A teacher in a TEFL context would need to have more extensive knowledge of all of his/her student' languages and cultures in order to incorporate them all equitably and meaningfully in class (Jenkins, 2010). 


\section{The Objectives of Cultural Teaching in TEFL}

Culture is a literally complicated concept, which is difficult to define. Different people may have different understandings of it. Raymond Williams (1983) calls culture "one the two or three most complicated words in the English language." Historically, much of the difficulty in defining and understanding the definition of culture actually is due to its multiple usages.

Culture is a fuzzy set of basic assumptions and values, orientations to life, beliefs, policies, procedures and behavioural conventions that are shared by a group of people, and that influence (but do not determine) each member's behaviour and his/her interpretations of the meaning of other people's behaviour (Spencer-Oatey, 2008).

On account of the complexity of culture, we cannot avoid inclination or emphasis on a certain aspects of it. All we have to do is to associate cultural teaching with the syllabus of English teaching. Thus the culture that must be studied refers to the culture, the narrowed one.

To know another culture is a rather difficult job. To act or behave appropriately in another culture is a more demanding task. It is even claimed that a satisfactory fulfillment of this task will take about 20 years. Keeping this in mind and also realizing the facilitating role of cultural knowledge in language learning, teachers must know the objectives of cultural teaching in TEFL. Principally, there are at least three objectives for them to teach in their language class.

1) To get the students familiar with cultural differences;

2) To help the student transcend their own culture and see things as the members of the target culture will;

3) To emphasize the inseparability of understanding language and understanding culture through various target classroom practices;

4) To emphasize communicative culture and make sure the students communicate with foreigners successfully.

\section{How to Carry out Cultural Teaching in TEFL}

\subsection{Create the Atmosphere of English Culture, Stimulate the Students' Interest of Studying}

It is important to create a friendly and stimulating learning atmosphere. The teachers should make the settings full of western cultural atmosphere. First they can put pictures on the walls of the classroom, like the map of the United States and that of the Great Britain, the Statue of Liberty in the US, popular English singers like backstreet boys, or famous English football stars etc. All of these are the favorites of the middle school students'. The can stimulate their strong interest and deepen their understanding of cultural concepts. Second, provide the students (especially the primary school students) a 100\% English environment. The teachers will speak almost everything in English, and the students are trained to understand the teachers immediately. No Chinese is used in English class. The requirements in creating $100 \%$ environment are the followings: 
1) The language materials must have a close relationship with daily life;

2) Try to use models, pictures, or real objects;

3) Special voices or facial expressions and body languages are necessary under some occasions.

4) Let the students meet and use the new materials repeatedly.

Besides the two points mentioned above, telling stories on English or American holidays are also quite valuable: Thanksgiving Day, and Valentines' Day... all is necessary to introduce the origins and customs of these holidays. The teachers can also make a comparison between traditional Chinese holidays and those of English speaking countries. Thus the students may have a thorough understanding of cultures of home and abroad. In addition to this, Greek and Roman mythologies permit the literary history of English people, which provide innumerous material for English teaching and research. Meanwhile, a comprehensive understanding of those tales and traditions may shed light on the students' comprehension of Chinese culture and tradition. In doing so, it is also of vital importance for the teachers to highlight the significance of Chinese culture and strengthen the cultural self-confidence. Without cultural self-confidence, the teaching of English and English culture will lose the socialistic direction, so we must handle the relationship between traditional culture and Western culture cautiously.

\subsection{Value the Positive Transition of Chinese Culture Sufficiently in FEFL}

The forming of culture is based on many factors like a nation's history, geographical features and social structures and so on. Therefore different nations have different cultures. The same thing may share different connotations by cultures from different nations. Take the "dragon" for instance, the Chinese people regard it as the symbol of nobleness and authority. However, in the eyes of the western people it is something evil and cruel that can eat human beings.

Despite the differences, Chinese culture and English culture also share some similarities. In both English and Chinese the word "ass" has the meaning of "being stupid". Another example is the word "wolf", in Chinese there is an expression "se lang", while in English there is its equivalence "sexy wolf". As for the teaching of excerpts from nature writing, the teacher can associate the English Green literature, such as The Silent Spring, Walden, and I Wandered Lonely as a Cloud with Chinese works like The Book of Songs or some representative poems written by Tao Yuanming, Li Bai. As a matter of fact, Thoreau himself was deeply influenced by traditional Chinese philosophical thoughts represented by Confucius and Mencius, which had been introduced by Ralph Waldo Emerson. As James Whipple Miller (1972) states there is a "sameness" bridging the great gaps of culture and time, style and language, which yawn between the poetry of ancient China and that of $19^{\text {th }}$ century England. If the TEFL teachers pay enough attention to these phenomena and make full use of the positive transitions of Chinese culture in their teaching, their lessons will produce unexpected effect. 


\subsection{Apply the Cultural Knowledge to Daily Life}

Language is the means of communication ( $\mathrm{Hu}, 2008)$. The aim of learning a foreign a foreign is to use it in daily life. In order to reach this goal, the teachers may organize activities, which will promote the students' application of English. For example, the teacher can invite foreign teachers to give lectures, thus produce face-to-face communication occasions for the students. The teachers can also encourage the students to make friends with foreigners by writing letters or e-mail or telephoning. In their spare time, the teachers may also lead the students to make role-plays. The effect of these activities can go far beyond that of one period of class.

\section{Conclusion}

It is already shown by practice that cultural teaching in TEFL assists the students to understand and familiarize with cultures of English-speaking countries. TEFL teachers in China have already realized the importance of culture in the process of language teaching: they are trying to absorb the newest information about American or Britain cultural lives, and trying to put it into their teaching practice. However, how to conduct cultural teaching in TEFL is still a demanding work which needs the collaborated efforts of all the English teachers in China.

\section{Acknowledgements}

This paper is under the project of The Cultivation of Culture Awareness in English Literature Teaching and the project of The Application of Project-based Learning in Teaching Oral English. I am deeply indebted to all the team members, who offered invaluable advice and comments.

\section{Conflicts of Interest}

The authors declare no conflicts of interest regarding the publication of this paper.

\section{References}

Hu, Z. L. (2008). Linguistics. A Course Book (Second Edition). Beijing: Peking University Press.

Jenkins, S. (2010). Monolingualism: An Uncongenial Policy for Saudi Arabia's Low-Level Learners. ELT Journal, 64, 459-461. https://doi.org/10.1093/elt/ccq014

Kramsch, C. (2002). Language and Culture. New York: Oxford University Press.

Miller, J. W. (1972). English Romanticism and Chinese Nature Poetry. Comparative Literature, 24, 216-236. https://doi.org/10.2307/1769896

Qi, Y. C. (1992). Language, Culture and Comparison. Foreign Languages Research, 32, 3-10.

Spencer-Oatey, H. (2008). Culturally Speaking. Culture, Communication and Politeness Theory. London: Continuum.

Stern, H. H. (1983). Fundamental Concept of Language Teaching. Shanghai: Shanghai Foreign Language Education Press. 